\title{
GENERAL CONSIDERATIONS ON THE ENFORCEMENT (APPLICATION) OF LAW
}

\author{
Remus Daniel Berlingher, Ph.D \\ "Vasile Goldis" Western University of Arad \\ E-mail: berlingherdaniel@yahoo.com \\ GEORGETA VALERIA SABAU, Ph.d \\ "Vasile Goldis" Western University of Arad \\ E-mail: georgetasabau@yahoo.com
}

(Received January 2016; Accepted April 2016)

\begin{abstract}
Law is a system of norms developed and/or recognized by the state as norms guiding human behaviour according to the values of that particular society, establishing rights and obligations, principles and definitions, structures and relationships of social organization and activity that must be obeyed and which, when necessary, are insured by the coercive force of the state. Thus, the development of this system of norms is not an end in itself, but is intended to regulate all social relations, guide human behaviours and achieve the aims of the law. The enforcement of law is the process of translating legal rules into practice, through which the subjects of law obey and execute legal norms, and state authorities apply them, depending on their competence. The enforcement of law depends on a number of factors that shape law, such as its natural framework of existence, the historical context and the ethnic and national particularities of that community's development, the economic factor or framework, the framework and particularities of the political system, the cultural-ideological framework or factor, the international framework or factor, etc.
\end{abstract}

Keywords: legal rule, enforcement of law, act of individual application, analogy of law

\section{The concept of "enforcement" and "application" of the law (legal norms). Forms of law enforcement}

As a set of juridical norms, law does not have a separate existence and is not an end in itself. It is intended to regulate human behaviour and actual social relations occurring in reality. To this end, it must be translated into the immediate practice of these relationships and behaviours.

The complex process of translating legal norms into practice is generically called "enforcement" [1] or "application" [2] of law. The enforcement of law means the analysis of how the human factor receives and agrees with it, of whether it has an attitude of compliance by adopting a behaviour in accordance with normative prescriptions, or one of non-compliance by adopting a behaviour contrary to legal norms.

The two terms (enforcement and application), while expressing essentially the same process, are however not synonymous, as their scope is different. The concept of "enforcement" of law expresses the broad meaning of the process of 
translating legal norms into practice and carrying them out, also including the contents of the concept of "application.

The concept of "enforcement" [3] of law entails two ways or aspects in its accomplishment:

a) The translation of legal norms into practice by voluntary compliance with their provisions, without the intervention or unmediated presence of state authorities, by social subjects - natural and/or legal person, public or private, state bodies, organisations or non-governmental bodies, or others social subjects. This way of enforcing the law is the expression of the level of legal conscience among the members of society, and of the democratic civilisation in that society. It is also the expression of the qualitative level of law itself, i.e. of the consistency of its norms with the requirements, interests and values of members of that society. Voluntary compliance with legal norms is the main and most relevant way of enforcing law in a democratic, civilised society.

b) The second way of enforcing law is by translating legal norms into the practice of social life through the intervention of state authorities in this process, in some form or another. This is also called "application [4] of law, expressing the narrower meaning of the term "enforcement". It appears as a specialised activity of the state apparatus, carried out within the limits of powers established by law, i.e. of certain rights, obligations, procedures, forms and means of intervention, meant to ensure compliance with the norms of law. The "enforcement" activity is the corollary of the function of state power to "regulate" or "legislate" in social life; legislating without enforcing the norms would be devoid of meaning.

The two ways or directions of enforcing law (voluntary compliance and application by state bodies) should be understood as complementary, even if the former is "non-legal" - i.e. without involvement or intervention from the state - and the latter is legal par excellence - i.e. conducted by competent state factors. Of course, other factors contribute indirectly to law enforcement, through non-legal ways and means: cultural activity, school education, economic development, political activity, the media etc.

\section{Form and characteristics of the law enforcement act}

As a specifically legal way or path for law enforcement, "application" assumes, in its turn, various forms, means, procedures, steps, etc. through which state bodies translate the provisions of legal norms into practices. These means, forms, procedures etc. are, in turn, governed mainly by the procedural legal rules specific to the branches of law in which they are applied.

In legal literature, the notion of "application" of law (or legal norms) has been controversial [5], being understood and used under two meanings or forms: as normative application and as individual application. The majority of authors 
consider that the actual sense of the concept of application refers to individual application.

The form of individual application is the proper, concrete sense of the notion of "application" of law. It consists of all the procedures, means, methods, phases etc. through which competent state authorities translate, i.e. "apply", the provisions of the norm to concrete, individual situations in a given case. This set of procedures, methods, means, etc. to translate norms into concrete, individual practice, also bears the generic name of "act" or "acts" of application. The act of individual application has the main characteristic of always determining the emergence, modification or termination of a specific legal relation.

In relation to the two categories of acts, "normative" acts and acts of individual "application", the following highlights should be noted [6]:

- Firstly, the two categories of acts should not be understood as expressing exclusive and strictly delineated competences as pertaining to some power structures or other. In other words, if under the principle of separation of powers the act of "legislation" and the act of "application" are, in principle, separate, as distinct acts, being in the competence of distinct power structures - Parliament (legislative power), Government (executive power) and the Judiciary - this does not mean that those power structures and their acts are strictly, absolutely only legislative or only executive. The more nuanced understanding and delineation of these competences stems from the observation of at least the following realities and needs: Parliament, for example, is a normative, legislative structure of power par excellence; it can and must adopt, and thus enforce, a series of individual acts of application - for example, acts of individual application of provisions of the Regulations of the Chamber of Deputies or the Senate, aimed at a certain Member of Parliament; the Government - albeit an executive, enforcement body par excellence, may also issue a number of normative acts that are not in the competence of law. As regards judicial authorities, however, it should be underlined, in this context, that they do not have competence to issue generic normative acts, but only acts of individual application (judicial resolutions, decisions, sentences etc.) in relation to a specific case.

- A second highlight that must be made in this context refers to the meaning of the term "application" which, as results from the above-mentioned, must not be restricted or narrowed, or identified with the term or concept of "penalty", even if those terms are tightly correlated, in the sense that a penalty established for a certain action is always an act of application, but not all acts of individual application involve a penalty. "Application" can target, for example, achieving a specific behaviour, performing a positive social action or activity, fulfilling an obligation, establishing a function, a reward etc., and not necessarily a penalty. Penalty and, in a broader sense, engaging legal liability, are indeed acts of application, but they only occur in situations of unlawful conduct, whereas the 
Berlingher, D., Sabău, G. (2016)

General considerations on the enforcement (application) of law

concept of "application" of law is aimed at all human behaviours, both lawful and unlawful.

Between the two categories of acts, "normative" and "application" ones, there are both similarities and differences [7].

The elements that illustrate their similarity, their common essence, consist mainly of the following: both forms consist of legal acts issued by competent bodies of the state; both pursue the same goal: achievement of legality in society; both have constitutional order and laws as a legal basis.

Differences between the two categories of documents mainly consist of the following:

- while the normative act has a certain degree of generality, the act of individual application is essentially a concrete act, targeting a given situation or state of affairs, a case, and always determines the emergence, modification or termination of a specific legal relation;

- in terms of their effect over time, legislative acts take effect in time, are therefore applicable within the limits of the moment of entry into and exit from force, while acts of individual application begin to take effect at the time when they were translated into practice under its various forms: communication, notification, pronouncement, taking the specific measure or sanction, resolution of the case etc.;

- there are also differences with regard to the formal-legal conditions and procedures required for their validity. For example, the conditions and procedures needed for the implementation and validity of a law, decision or government order are different from those used in pronouncing a court sentence, drawing up a contravention act etc.;

- differences also exist on the issue of principles and forms of remedies or appeal to such acts, as follows: normative documents can usually be modified or cancelled only by the issuing body and, in some cases, only by hierarchical bodies (e.g. Parliament can invalidate an government ordinance or decision), while acts of individual application can be challenged, modified or cancelled in other ways such as: appeal, notification, complaint etc., usually filed to hierarchical organs;

- finally, acts of individual application are subordinate to legal acts and together, according to the rule of law, they are subordinate to constitutional order and state laws.

\section{Phases of application of legal norms}

Individual application is, by its content and its aim, a complex but unitary process in which a few relatively distinct but inseparable phases can be delineated [8]. The demarcation and establishment of their succession is a much more didactic than purely procedural approach, as these phases are intertwined and sometimes occur simultaneously or in parallel. 
Thus, the following related, interdependent phases can be delineated in the individual application procedure: establishing the state of affairs, establishing the legal elements and interpretation of norms, and, finally, developing a solution or provision of application.

Establishing the state of affairs is the first phase of applying the law. It involves a legal process by which the facts, conditions and circumstances relevant for understanding the situation or case to which law should apply are collected, recorded and retained. By establishing the state of affairs, one must reach consistency between the apparent facts, considered by hypothesis as true, and the objective reality of their occurrence.

Establishing legal elements is the legal operation that begins with the establishment of the state of affairs and consists of selecting or identifying the group of legal norms corresponding to that state of affairs and in which that state of affair would fit. This phase also bears the name of "critique" [9] of the norms of reference and entails, among other things, at least the following steps of attaining knowledge: determining whether the norms of reference identified and selected are in force or not; whether they have applicability in space over the individuals concerned; whether or not they are consistent with the higher regulations in force; whether or not there are clashes (conflicts or discrepancies) between selected norms and other legal provisions etc.

This phase also involves, by the logic of things, the operation of "interpreting" those legal norms. Interpretation of the chosen legal norm involves clarifying the real intention of the legislator. [10]

Developing the solution or the provision of application. This is the phase when the individual application itself is completed. It involves, in turn, two stages: individualisation and nomination of norms (articles) in which that state of affair can be fitted. In other words, at this stage of this phase occurs what is called legal classification of the offense. The second stage of this phase consists of developing the solution by establishing the application provision [11] of the norm to which that state of affairs was assigned.

In developing the solution, as a phase of individual application, one should also retain the observation that, through its content and form, the development of a solution or the application provision feature notable particularities from one branch to another law. In this regard, the content and form of a provision or solution of application are different, for example, in civil law, criminal law, family law, etc. All these phases should be understood as related, uniform and relatively successive in their development.

\section{Application (and interpretation) of legal norms by analogy [12]}

In practice there are situations where the law enforcement body, being tasked with the legal settlement of a case, cannot find a legal norm to assign to the state of 
affairs they must judge. In such cases, the judge cannot refuse to ajudicate the case on the grounds that the law does not cover it or that the regulation is incomplete. In these cases, the law is applied by analogy [13].

Analogy is a particular and currently rather limited, restricted form of application and interpretation of law. It was created and consecrated throughout the history of law by the needs of legal practice to compensate for the gap (lack) in express legal norms referring to certain states of affairs brought before the courts to be tried and resolved.

In essence, analogy consists of the possibility of the court seised of a state of affairs, a case, but for which there is no specific assigned norm, to apply to that case an existing norm, applied to a similar case.

The concept of application of legal norms by analogy has two meanings, namely: - "Analogy of the law" - which envisages the application of a law or legal norm from a similar case and,

- "Analogy of the legal system" - which envisages settlement of a case where there is no applicable legislative text or regulations from any similar case. In this instance the case shall be solved by applying the "general principles of law". This situation is even more rare and provided only under certain legal systems (for example, the Italian legal system admits it for the branch of civil law).

\section{Conclusions}

The enforcement of law is the process of translating legal rules into practice, through which the subjects of law obey and execute legal norms, and state authorities apply them, depending on their competence.

The complex process of translating legal norms into practice is generically called "enforcement" or "application" of law. The enforcement of law means the analysis of how the human factor receives and agrees with it, of whether it has an attitude of compliance by adopting a behaviour in accordance with normative prescriptions, or one of non-compliance by adopting a behaviour contrary to legal norms.

The concept of "enforcement of law entails two ways or aspects in its accomplishment: the translation of legal norms into practice by voluntary compliance with their provisions, without the intervention or unmediated presence of state authorities, and the second way of enforcing law is by translating legal norms into the practice of social life through the intervention of state authorities in this process, in some form or another.

The two ways or directions of enforcing law (voluntary compliance and application by state bodies) should be understood as complementary, even if the former is "non-legal" - i.e. without involvement or intervention from the state - and the latter is legal par excellence - i.e. conducted by competent state factors. Of course, other factors contribute indirectly to law enforcement, through non-legal ways and 
Berlingher, D., Sabău, G. (2016)

General considerations on the enforcement (application) of law

means: cultural activity, school education, economic development, political activity, the media etc.

\section{Notes}

[1] Craiovan, I. (2015), Tratat de teoria generala a dreptului, editia a III-a, Universul Juridic, Bucuresti, p. 482

[2] Bobos, G., Buzdugan, C., Rebreanu, V. (2008), Teoria generala a dreptului, Editura Argonaut, Cluj Napoca, p. 227-228; Dvoracek, M.V., Lupu, G. (1996), Teoria generala a dreptului, Editura Fundatiei Chemarea, Iasi, p. 256-270.

[3] Popa, N. (2012), Teoria generala a dreptului, Editura C.H. BECK, editia a IV-a, Bucuresti, p. 192-197

[4] Cristea, S. (2014), Teoria generala a dreptului, Editura C.H. BECK, Bucuresti, p. 77

[5] Popa N. (2012) in op. cit., p. 196 express reservations about the notion of "normative application" used by Gh. Bobos, considering that the concept of "application" has proper meaning only as "individual application". In the 1994 edition of Teoria generala a dreptului (General Theory of Law), Gh. Bobos no longer uses the term "normative application".

[6] Ceterchi, I., Craiovan, I. (2001), Introducere in teoria generala a dreptului, Editura ALL BECK, Bucuresti, p. 94.

[7] Idem; Gh. Bobos, op. cit., p. 228-231.

[8] Gh. Bobos, op. cit., p. 231-233

[9] I. Craiovan, op. cit. p. 485

[10] With reference to the interpretation of the legal norm, see more broadly, S. Cristea, op.cit. p. 29-36

[11] The application provision has two meanings: 1. Provision - in the sense that the set solution indicates the action, inaction, behaviour, right or obligation to be followed and obeyed in accordance with the provisions of the applied norm and, 2. Provision in the sense of "penalty" established under applied legal norms and its concrete way of execution.

[12] I. Ceterchi, I. Craiovan, op. cit., p. 96

[13] I. Craiovan, op. cit., p. 486

\section{Bibliography}

1. Bobos, G., Buzdugan, C., Rebreanu, V. (2008), Teoria generala a dreptului, Editura Argonaut, Cluj Napoca

2. Craiovan, I. (2015), Tratat de teoria generala a dreptului, editia a III-a, Universul Juridic, Bucuresti

3. Ceterchi, I., Craiovan, I. (2001), Introducere in teoria generala a dreptului, Editura ALL BECK, Bucuresti

4. Cristea, S. (2014), Teoria generala a dreptului, Editura C.H. BECK, Bucuresti

5. Dvoracek, M.V., Lupu, G. (1996), Teoria generala a dreptului, Editura Fundatiei Chemarea, Iasi

6. Popa, N. (2012), Teoria generala a dreptului, Editura C.H. BECK, editia a IV-a, Bucuresti 